\title{
The Religious Sexual Education in Post-Revolutionary Iran: Redefining Tamkin and the Control of Sexuality
}

\section{Nafiseh Sharifi}

\begin{abstract}
This paper looks at the religious discourse of sexuality in post-revolutionary Iran. Based on my ethnographic fieldwork in Tehran, I discuss how in state-sponsored publications and official education traditional religious rules of sexuality such as tamkin are redefined in relation to society's new demands. I discuss the role played by religious workshops for married couples in justifying Islamic moral codes of behaviour that regulate and control Iranians' sexual lives. However, this paper argues that Islamic sex education is changing the perception of sex and female sexuality amongst its young religious audience. Such changes and their effects on women's sexual lives might not, however, be in accordance with the state's sexual policies. Consequently, younger of women use religious justifications to learn more about sex and increase their own sexual satisfaction in marriage. I argue that it is important for feminist scholars to highlight the complicated effects of disciplinary discourses in order to understand women's lives in Muslim societies.
\end{abstract}

Keywords: Tamkin, religious sex education, Islamic Feminisms

Sharifi, Nafiseh. 2019. 'The Religious Sexual Education in Post-Revolutionary Iran: Redefining Tamkin and the Control of Sexuality.' Gender a výzkum / Gender and Research, Vol. 20, No. 2: 68-83, http://dx.doi.org/10.13060/25706578.2019.20.2.484.

Last year, I was teaching an undergraduate course at Al-Zahra University in Tehran. Al-Zahra is a women-only university that was established right after the Islamic Revolution, and it is a high-ranking university that mostly women from religious and conservative backgrounds attend. In my class the majority were fully covered. ${ }^{1}$ Similar

1 By full hejâb I mean wearing châdor, which is a top-to-toe shapeless and loose-fitting black cloth specific to Iran. Currently there are different types of Châdor that Châdori women (women who wear châdor) wear in different places and for various occasions. For example, we have châdor-e melli (national châdor), châdor-e Qajari (similar to women's clothings during Qajar time in Tehran), châdor-e daneshjooyi 
to my experience at other universities, my students at Al-Zahra asked me about my field of study and seemed eager to learn more about 'gender studies'. They asked if instead of sociology I could teach them 'gender'. Based on the questions they asked I realised that they simply wanted to learn more about 'sex' and 'sexual relations'.

For example, one of the religious students ${ }^{2}$ in the class asked me with a worried tone: 'how can we make sure before marriage that our suitor does not have any sexual problems?' By 'sexual problems' she meant deviant or abusive sexual behaviours that occur during sexual intercourse. I could understand her worries; as a practising Muslim she could not have any forms of sexual contacts with her suitor before religiously becoming his wife. ${ }^{3}$ In addition, she was aware that in order to find a suitable husband she had to conform to the norms of female virginity before marriage.

Still, for me it was interesting to see how 'sex' had become so important in the lives of these young women. I could not imagine talking about my sexual concerns publicly and in front of my classmates. Like my students at Al-Zahra, I was born after the Islamic Revolution and grew-up in a religious family, but I remember I was more concerned about my future husband's social status, education, and level of religiosity than his sexual problems. What has changed? Why are these young, unmarried women from religious and conservative backgrounds so concerned about sex and are not embarrassed to talk about it?

In 2012 and 2013, while I was conducting ethnographic fieldwork in Tehran and interviewing women from two different generations, I learned about the religious sex education for married couples that was being sponsored by the Islamic Development Organisation ${ }^{4}$ (Sharifi 2018). At that time, I attended a one-day sexeducation workshop for married women, which I describe later in this paper, and in that workshop I observed how the dominant religious discourse was appropriating traditional religious rules in relation to new sexual and marital concerns of young, educated, and religious women.

Based on my recent experience with students at Al-Zahra University, I decided to

(university students' châdor), etc. Each type is popular amongst a group of women according to their lifestyle and their level of religiosity. Châdor also represents a woman's economic background, as quality and prices also vary.

2 I judge her level of religiosity based on her appearance and the fact that she missed three weeks of classes to attend the Arba'een walk, which is a large Shi'a pilgrimage held every year in Karbala, Iraq to commemorate the 40th day after the martyrdom of Hussain Ibn Ali, the third Imam of Shi'a.

3 Religious women cannot be in relations or contact with nâ-mahram men. A mahram relationship is formed either through birth or marriage. Mahram people (mostly close family) can socialise, while nâmahram refers to unrelated men and women whose interaction is forbidden unless the rules of gender avoidance, such as veiling, are observed.

4 The organization was founded in 1981 and it is overseen by the supreme leader of the Islamic Republic. For more information, see the organisation's website: http://ido.ir/. 
take a deeper look at the sexual information that young people receive from religious and public media sources. In this paper, I focus on the work of Mr Dehnavi and his religious sex education. I analyse the content of his workshops for married men and his recently published DVDs in relation to the sexual policies of the Islamic Republic and recent socio-cultural changes in Iran. I chose Dehnavi because he is a religious and public figure; a clergyman who has programmes on the Islamic Republic's national television, organises workshops for couples, and has written a huge range of publications on marriage and marital relations. Seminary institutions and state organisations also sponsor his work and publications.

Based on my qualitative analysis, below I discuss how, in the state-sponsored publications and religious sex-education workshops, the socio-cultural norms of female and male sexualities are redefined in relation to changes in the younger generation's perceptions of sex and marital relations. More specifically, I describe how, in religious sexology discourse, traditional religious rules such as tamkin are redefined and justified. I argue that understanding the changes in the dominant Islamic discourse opens a space for feminist scholars to ask for new interpretations of religious texts and consequently change the legal laws that keep women in a subordinate position.

I follow the discussion that argues women's sexual rights and the understanding of women's sexuality are not fixed in Islam and that they are 'changing cultural constructs produced in relation to lived realities' of men and women throughout the Muslim world (Mir-Hosseini 1999: 6). Simply categorising Islam as the main cause of women's oppression and looking for acts of resistance to religious regulations (Moghissi 2002; Adelkhah 2004; Moaveni 2005; Mahdavi 2008; Afary 2009) ignore the changing aspects of religious discourse and its complicated effects on women's lives in Iran and other Muslim societies. Instead, we need to look at the possibilities and opportunities for action that the dominant disciplinary discourses create in the lives of women (Mahmood 2005).

According to Foucault, disciplinary power works in a paradoxical way: while the main purpose is to control and homogenise the social body, it creates points of resistance and enables individuals' capacity for action (1980: 291-292). For Foucault, power is not something that works negatively by prohibiting, restricting, denying or repressing; instead, he defines power positively, as something that produces new forms of pleasure, systems of knowledge, and discourses (ibid.: 119).

Drawing on Foucault, I argue that while the aim of religious sex education in recent years has been to justify Islamic moral codes of behaviour and regulate and control Iranians' sexual lives, it has also introduced new concepts of sexuality and changed the perception of sexual relations among its young religious audience. More importantly, religious sex education gives women religious grounds on which to challenge general socio-cultural perceptions of female sexuality in the Iranian context. 


\section{Religious Sex Education}

During my fieldwork in 2012-2013 in Tehran I heard about Hajagha ${ }^{5}$ Dehnavi, a clergyman in his fifties who had a live programme on national television in which he discussed couple's sexual problems (Sharifi 2018: 52). At that time many of my religious relatives found his programme useful and advised me to follow and watch it. One Thursday afternoon while I was at my parents', I watched Dehnavi's live programme. During that programme he received a phone call from a woman who was seeking advice on how to solve her husband's problem of premature ejaculation. To answer her question, Dehnavi explained the possible factors that could be causing this problem and encouraged the couple to see a psychologist or a medical doctor. I was amazed not only by the woman's unhappiness about her husband's premature ejaculation and by Dehnavi's explicit response, but even more so by the fact that I was watching it live on the Islamic Republic's national television channel. Growing up in the 1990s, I do not recall watching any television programmes like this in Iran.

The women I encountered had different reactions to the content of his programme. For example, younger religious women criticised his explicit language and the fact that the programme aired during the daytime on Thursdays. ${ }^{6}$ One of my friends described finding her six-year-old on staring at the television watching Dehnavi's programme, and she was furious because she did not expect her child to receive inappropriate sexual information from a legitimate religious source. My friend and her husband deemed satellite television un-Islamic, especially because of its inappropriate sexual content, and they trusted national television to broadcast safe content for children during the day.

The television programme was called Golbarg-e Zendegi and it aired from June 2008 to June 2013. During the series Dehnavi addressed topics such as finding a spouse, having a successful marriage, the differences between men and women, and couples' sexual relations. For the purpose of writing this paper, I searched for the programme's archive, but it was not available online. I asked one of my old friends who works at national television and she gave me the producer's number. During our short telephone conversation the producer explained to me the reasons behind the programme's cancellation: 'the organization [Islamic Republic of Iran Broadcasting (IRIB)] asked us to stop producing the programme without giving us any explanations, they only said that if we wanted to continue we had to change the programme's expert [Dehnavi was the programme's main expert]'. When I asked about the sexual

5 Hajagha describes a man who has been to Mecca. In everyday language, though, people refer to elderly and religious men with the term Hajagha. The term is also used to describe clergymen.

6 In Iran the working week is from Saturday to Wednesday and the weekend is Thursday and Friday. Many people and families were thus able to watch Dehnavi's television programme. 
content of the programme, he said that 'it was during the final twelve episodes that Mr Dehnavi talked specifically about the topic of desire and sexual relations'. Based on his description, I assumed that discussing sexual relations on a live television programme had caused difficulties for them. However, by cancelling his television programme, the state and other religious institutions gave Dehnavi other platforms on which to continue offering his sex education. For example, the television programme has been published in four volumes by a religious publication company based in Qom ${ }^{7}$ and is available to order online. ${ }^{8}$

In addition, since 2013 Dehnavi has been organising workshops for married people which have recently been reproduced as a series of DVDs titled 'the art of lovemaking'. There are three DVDs in this series and in each Dehnavi addresses different aspects of sexual relations between couples. In one of the DVDs, he explains the reasons for producing the series: 'I couldn't continue the live programme because there were many reservations and many red lines'. He emphasises that the public sphere was not ready for the sex education he was offering in a live television programme. Therefore, he organises workshops instead, where he discusses sexual relations clearly and explicitly for people who are eager to learn:

I feel responsible. I am not encouraging sensuality or promiscuity among people. As a clergyman who has his own family, I cannot have evil intentions. My main aim is to increase the quality of Iranian people's sexual lives with the help of our Islamic culture. I am not talking outside of the religion; it all exists in our religion.

Dehnavi is a perfect representative of religious sex education in post-revolutionary Iran. Traditionally, generations of religious ulama ${ }^{9}$ responded to people's sexual concerns in Towzihul Masâ'els:"10 they provided 'expert advice on the dos and don'ts of sexual relationships, thereby not only helping believers make sense of their carnal desire, but also controlling their sexual expression within the confines approved by the Shari'a (Shahidian 2008: 103). In the traditional religious discourse of sexuality 'there are no discussions of women's sexual satisfaction' and it is full of 'commands and warnings', mostly aimed at men, about the 'rights and duties of each spouse in marriage' (Mir-Hosseini 2004: 3-4).

7 Qom is Iran's second holiest city and is home to Shiite Ulama and seminary schools.

8 For more information about the book series, see: https://bit.ly/2xA5PLF

9 Religious leaders, experts of Islamic texts, and laws.

10 Most religious leaders have a Towzihul Masâ'el. This is a book that might contain questions and answers regarding religious regulations about virtually any issue of interest to followers of a particular Marja'-e Taqlid (a religious authority who can be followed as source of imitation), from regulations concerning ablutions, to banking, to sex and so forth (Shahidian 2008: 103). 
However, these texts are not compatible with the sexual issues and problems of young Muslim people living a modern lifestyle (Shahidian 2008). In fact, young people today receive information about sex from different sources, such as the Internet, satellite television, Hollywood movies, and pornographic content distributed on social media. ${ }^{11}$ Such information can cause anxiety as it normalises aspects of sexualities and sexual relations that might be different from a couple's life. For instance, during my fieldwork in 2012 I interviewed a family consultant and she told me that the majority of couples who asked for consultation had sexual problems. As I have described in detail elsewhere, she spoke about a young couple that 'became concerned [they] were not having enough sex because the films they watched indicated a higher level of sexual activity to be the norm' (Sharifi 2018: 44). At that time, in my interviews with women, I also noticed that many of them compared their own sexual experiences with sexual relations they had seen in television series ${ }^{12}$ and Hollywood movies (ibid.: 44-45).

In addition, large-scale studies conducted in major cities in Iran have shown couples' sexual dissatisfaction to be the main reason for divorce (Farnam et al. 2008). Recent statistics indicate that sixty percent of divorces in Iran are the result of a couple's sexual problems, and mainly their sexual dissatisfaction (Salamat News 2016). According to statistics, in 2001 women petitioned for a divorce more often than men, and that year's figure had doubled by 2008; at that time, the average divorce rate in Tehran was 'one in every five marriages' (Afary 2009: 361, 363). 'The growing desire for intimacy and companionship in marriage' is considered an influential factor in the increasing number of women filing for divorce (ibid.: 362). In 2005, 53\% of women who asked for divorce 'were [also] dissatisfied with their sexual relationships' (Farnam et al. 2008: 161).

In fact, due to the demographic shift to a younger population, the rise in the average marrying age, and the increased presence of women in the Iranian public sphere, it has become crucial for the state to control and regulate Iranian people's sexuality by introducing alternative sex education programmes based on Shi'a theology. Therefore, as Shahidian discusses, many Muslim scholars have started to compare and redefine scientific knowledge of sex and sexuality in relation to Islamic education (Shahidian 2008: 105). The knowledge this has produced has mostly targeted an urban, educated audience observant of Islamic teachings.

However, Dehnavi is the first clergyman to discuss sexual relations in Iranian public media. Still, by emphasising the fact that he is a clergyman and has no 'evil intentions', Dehnavi hints at the contempt he has been show by both the religious and the

11 For more on Iranians' use of the media, see: Sreberny and Khiabany (2010) and Alikhah (2008).

12 Especially Turkish television series, which are very popular in Iran. 
non-religious segments of Iranian society. ${ }^{13}$ Based on his knowledge of Shari'a, he claims that there is no need to use Western sexology, as 'all' the sexual knowledge needed to improve Iranian couples' sexual lives already exists in Islam. By simply following religious guidance, couples can increase their sexual satisfaction, create happy families, and enjoy their marital relations.

Based on an analysis of the discourses of sexuality in post-revolutionary Iran, Shahidian (2008) discusses the work of Muslim scholars in producing modern, scientific, and Islamic knowledge of sexual relations that is based on the binary of active male and passive female sexualities. He argues that while the knowledge produced in this emphasises women's enjoyment of sex, religious scholars and specialists still tell their audience 'that all a woman has to do is lie quietly and let her husband do his business' (Shahidian 2008: 114). In this respect, Dehnavi's sex education represents a change in the dominant approach to sexual relations in post-revolutionary Iran, because, in contrast to previous religious scholars, he is acknowledging how couples' sexual expectations have changed and accepting the need to redefine traditional religious rules and advice in relation to new demands.

In fact, Dehnavi's educational information is inherited from centuries' worth of sexual knowledge in the work of ulama and Muslim scholars. However, he does not rely on the textual medium like they do and uses new platforms such as organising workshops or publishing DVDs in order to reach a wider spectrum of the Iranian populace.

Although only married couples can attend his sex-education workshops, the recorded videos are available online and anyone can watch them for free on Aparat. ${ }^{14}$ The DVDs are also sold on a website that belongs to seminary students in Qom. The accessibility of his videos highlights a contradictory aspect of the Islamic Republic's sexual policies: while the state denies sexual activity among youth before marriage and avoids offering any form of official sex education, ${ }^{15}$ young and even under-aged kids can watch Dehnavi's programmes online and receive sexual information from a religious authority approved by the state.

13 He has been mocked and ridiculed on social media, mostly by non-religious Iranians, for his use of religious advice. Searching online I discovered that he was once referred to as 'Sultan [king] of pornography'.

14 Aparat (https://www.aparat.com) is an Iranian video-sharing website similar to YouTube. While YouTube is blocked in Iran, Aparat is accessible to everyone. The content of shared videos on Aparat are revised and checked according to Islamic Regulations, but there are no age limits or parental control. Therefore, anyone can share and watch any videos on Aparat as long as the content is not un-Islamic. 15 In 2011, Ayatollah Khamenei publicly announced that the family planning campaign that was initiated in 1988 was a 'mistake' and said 'we have to increase the population to 150 million' from the current 75 million (Seyed Ali Khamenei, Speech at the National Congress on Changes in the population and its role in social changes. Originally published 28 October 2013. http://farsi.khamenei.ir/speech-content?id=24344). For more information on the state's recent pro-natalist policies, see Homa Hoodfar's article (2017). 
In the next section I focus on the second part of Dehnavi's 'art of lovemaking', as I find its content and Dehnavi's use of language to be very explicit and different from the general socio-cultural perception of marital relations.

\section{'Sex Is Not Just for Men'}

The second DVD was recorded at one of Dehnavi's workshops for married men in Qom. In this programme he specifically explains sexual arousal and orgasm among men and women and emphasises the importance of sexual satisfaction in order to increase the 'quality of sexual relations' between spouses. He explains:

Both men and women have sexual needs. I first mentioned [this point] in a television programme and we received many strange responses from the audience - a guy texted us saying that he had been married for 20 years and he had never thought that his wife had sexual needs. Can you believe we still have such beliefs in our country?

Dehnavi adds that in Islam, in contrast to the general perception, there is an emphasis on women's sexual satisfaction: 'women also have sexual needs, but because of the shyness that God places in them, this is not apparent before marriage'. Dehnavi's sexual education is based on the binary understanding of female and male sexuality. He still defines female sexuality in relation to men by denying women's sexual needs before marriage. In addition, he essentialises the socio-cultural understanding of a sexually unaware, chaste, and shy woman as God's command. However, he taught his audience that sex is a source of pleasure not just for men, and that women can also enjoy sexual intercourse and experience orgasm:

Prophet Muhammad said two things are a sign of weakness: a man who sleeps with his wife without showing kindness to her, and a man who is sexually satisfied before his wife. A man from the audience asked the Prophet: how should a man satisfy his wife? The Prophet replied: he has to wait until they both reach enzal [ejaculation]. Gentlemen, please take this seriously. If a man is aroused without satisfaction it does not do him any harm, but if a woman is aroused and does not reach orgasm then it has many harms such as women's betrayal and corruption. The Prophet said that God puts the patience of ten men in one woman, but if a woman is sexually aroused then her lust is the equivalent of ten men.

In Iranian society, men and women have learnt to perform according to the norms of passive female and active male sexuality. Men are considered to have uncontrollable 
sexual urges and they have more sexual freedom. In contrast to men, women have learnt to be ashamed of their sexuality, to conceal their body, discipline their sexual desire, and act according to the norm of female virginity. Both genders are familiar with the double standard relating to virginity, as it is socially more acceptable for men to have pre-marital sexual relations (Varzi 2006).

In a binary understanding of female and male sexualities, women have internalised the notion that, unlike men, women enjoy emotional contact more than they do physical/sexual relations. However, as Dehnavi notes, after marrying and experiencing sexual intimacy with their husband, women turn into sexual beings with similar sexual needs. Many women have faced difficulties in their marital relations, as suddenly in married life they were expected 'to know everything about sex and actively participate in sexual relations' (Sharifi 2018: 140).

Dehnavi's and similar examples of religious sex education should be contextualised in relation to recent changes in Iranian society. For many young, educated people, reproduction is not the primary goal of marital relations anymore. The state's population policies, especially the family planning campaign that started right after the Iran-Iraq war, established new approaches to sexual relations not limited to procreation. In order to control population growth, the state used public media and religious discourse to create an image of a happy family with fewer children (Hoodfar, Assadpour 2000: 23-29). The campaign was successful in educating younger generations of Iranians. Moreover, because of the recent economic situation many young married couples feel they cannot afford to have more children, if any at all. More importantly, as I mentioned before, exposure to images of marital/sexual relations from different media sources has given rise to new sexual concerns and expectations amongst the younger generations of Iranians.

It is in this context that Dehnavi's provision of information about sex, especially in the workshops he organises for married men, gains its significance. He does not question men's greater sexual needs or their right to polygamy, but he recognises women's sexual needs and sees their sexual satisfaction as their husband's responsibility in marriage. Dehnavi says that if a woman masturbates ${ }^{16}$ it is her husband's sin not hers. Also, if a man has more than one wife and one of his wives commits Zina ${ }^{17}$ (or Zena), it is her husband's fault, because he was unable to sexually satisfy her.

In Dehnavi's discourse, unsatisfied married women, women who are sexually aroused but not satisfied, are the main source of corruption and fitnah in society

16 In Shari'a masturbation is haram for both men and women.

17 An Islamic legal term referring to 'any act of illicit sexual intercourse between a man and a woman. The punishment for zina is the same for men and women; 100 lashes for the unmarried and death by stoning for the married' (Mir-Hosseini 2010: 21). 
(Sabbah 1984). Therefore, it is important to educate men in how to respond to their wife's sexual needs and how to please them. According to Dehanvi, in order to control sexual relations in society, it is crucial to control and satisfy female sexuality at home. Consequently, he explicitly explains women's 'stimulation points' (i.e. erogenous zones) and how men can use them to prepare their wives for intercourse. He refers to a hadith ${ }^{18}$ from Imam Sadiq ${ }^{19}$ who said: 'do not have intercourse with your wives unless you have had played with them by rubbing their breasts until you see the lust in their faces and in their eyes'. Dehanvi encourages his young male audience to sexually arouse their wives by being affectionate to them throughout the week and especially the night before they want to have sex:

Imam Sadiq (peace be upon him) said that when a Muslim man wants to sleep with his wife he should engage in foreplay [mola'ebeh] with her as it is better [for sexual relations]. Or Prophet Muhammad (peace be upon him) said three things are considered cruel: one is a man who has sex with his wife without first preparing her.

Dehnavi cites physiological and scientific facts, but without giving any references, to prove the importance of 'foreplay'. The scientific facts are presented mainly in order to appeal to a wider spectrum of the Iranian audience and to prove the practicality of religious regulations in modern life. For example, he mentions that the lack of mola'ebeh (foreplay) is one of the causes of infertility in women. He also advises his audience that if you want your child to be a boy then sexually arouse your wife, and if you want a girl then avoid foreplay, because when a woman is sexually aroused it affects the PH level in her uterus and this determines the baby's gender.

By presenting an image of a marital relationship based on mutual sexual pleasure and satisfaction, Dehnavi redefines tamkin. Sexual submission or tamkin is 'a husband's right and a wife's duty' (Mir-Hosseini 2002: 137). Legal marriage contracts 'define a default set of fixed rights and obligations' for men and women, which revolve around 'the twin themes of sexual access and compensation'20 (Mir-Hosseini 2010: 47). It is a wife's duty to 'live under her husband's roof and be sexually available to him at almost any time', and it is a husband's duty to provide his wife with shelter, food, and clothing (Shahidian 2008: 113). According to law, there are two types of tamkin: tamkin-e âm (general) and tamkin-e khâs (specific). While the general tamkin refers to 'women's recognition of her husband's authority [...] as a head of

18 Stories attributed to the Prophet Mohammad and twelve Imam of Shi'a.

19 Ja'afar al-Sadiq was a sixth Imam of Shi'a and an influential figure in creating Shi'a ideology.

20 Compensation or nafagheh (nafaqa). 
a household', tamkin-e khâs is defined as 'the woman's readiness for her husband's demands for sexual satisfaction' (Tizro 2013: 101-102). Woman's disobedience in either respect is noshooz. A woman who 'does not tamkin loses her entitlement to nafagheh' and her husband can 'cite sexual irresponsiveness as a ground for divorce' (Shahidian 2008: 113). A woman can also ask for divorce if her husband refuses sex for four months. However, proving this is very difficult, and the court will usually 'grant a woman divorce on this ground only if the husband suffers from an incurable disease, or has disappeared for over six months' (ibid.). In addition, 'a man can refuse sex as punishment for his wife's noshooz, but a woman cannot refuse sex for any reason unless her husband's demand contradicts the Shari'a (ibid.). Moreover, if men's sexual needs are not satisfied at home, they legally have the right to acquire another wife, whether temporarily ${ }^{21}$ or permanently.

Dehnavi does not question the religious or legal aspects of tamkin that put women in a subordinate position. His description of a happy and satisfied marital relationship is still based on men's right to unlimited sexual access. However, he contradicts the traditional religious education by reminding his male audience that you cannot expect your wives to be sexually available without showing them affection and love. Moreover, instead of repeating the general understanding of tamkin as meaning women should be sexually available to their husbands whenever or wherever the husband wants, ${ }^{22}$ Dehnavi explains that men should prepare their wives first and respect their wishes and desires for intercourse. A few times during his speech he also addresses women by encouraging them to play an active role during sexual intercourse: 'most of our women act like a marble stone during sex, they are very beautiful [like marbles] but they just lie down like a stone and do nothing'.

Similar sex-education workshops are also organised for married women. In 2012, as part of fieldwork for my thesis, I attended one of these one-day workshops in Tehran (Sharifi 2018: 50-52). Only married women, with a marriage licence as proof, could attend the workshop. The main purpose of the workshop was to educate young married women about the importance of sexual relations for maintaining a successful and happy marriage. During the workshop, the female speaker, who had a seminary background, taught her audience how to choose sexy underwear, how to initiate sex, how to write amorous and sexy text messages, and how to experience and enjoy different sexual positions with their husband. Without showing or using any additional photos or videos, she described in detail ways to give and receive pleasure

21 Temporary marriage (siqeh or mut'a) is allowed in Shi'a jurisprudence and has been practised freely in Iran (Haeri 1989). Siqeh is 'a contract with a definite duration (from a few minutes to ninety-nine years) [which] legitimises a sexual union as well as the children born into it' (Mir-Hosseini 1999: 69).

22 There is a famous hadith attributed to Prophet Mohammad that says: 'Women must give a husband sex even if they are on the back of a camel' (Al-Kulyani 1379 Volume 5: 507) 
and encouraged her audience not to be ashamed of sex and to play an active role during sexual intercourse.

In the workshop for married women, tamkin was the main topic. The lecturer reminded her audience that their place would be 'in hell' if they did not sexually submit to their husband. However, she encouraged her audience to look at sex not simply as their duty but as a way of showing love and affection for their husband. Similar to what Dehnavi argued, she emphasised that sex was important for both men and women and by playing an active role, in such ways as initiating sex and being open to experiencing different sexual positions, women could increase both their own and their husband's sexual pleasure in marriage.

Dehnavi's DVD and the workshop for married women complete with each other as both address the same issue: the sexual relationship between married partners. While Dehnavi focuses on mutual sexual satisfaction and educates his young male audience to be attentive to their wife's sexual needs in marriage, the female speaker in the workshop repeatedly mentioned tamkin as women's only responsibility in marriage. By using different strategies both try to regulate and control the sexual life of modern, young, and educated people in accordance with Sharia.

However, the changes in their use of words highlight the changes in perceptions about sexual relations among young religious men and women. For the young audience, simply representing tamkin or sexual submission as a man's 'right' and a woman's 'duty' is not compatible with their ideal of sexual relations anymore. Therefore, the dominant religious discourse makes sure that couples know how to respond to each other's sexual needs and represents sexual relations as a source of mutual enjoyment and pleasure for both men and women. Still, the information about sex that is offered indirectly justifies rules such as tamkin.

\section{The Contradictory Aspects of the Islamic Republic's Religious Sex Education}

Religious sex education is a disciplinary discourse as it is aimed to regulate and control the sexual lives of Iranians based on religious rules such as tamkin. Like Foucault's (1980) depiction of disciplinary power, I emphasise the indirect and positive aspects of religious sex education in the lives of young married men and women, because I find Islamic sex education to be both 'disciplinary' and 'emancipatory', especially for young Iranian women.

Najmabadi discusses how the creation of the modern Iranian female subject was based on a similar contradiction, as there were both 'emancipatory and disciplinary impulses' (Najmabadi 1998: 91). The emancipatory aspect of modern education provided women with 'a place in the nation' and the opportunity to 'become 
citizens' (ibid: 113). However, this 'place' was achieved through 'self-policing' and an internalisation of the regulatory and disciplinary practices not previously enforced in women's domestic lives (ibid.).

Similarly, while the main purpose of Islamic sex education is to create sexually satisfied men and women, it gives couples, especially women, religious grounds on which to ask for sexual satisfaction and sexual pleasure in marriage. In fact, religious sex education creates a legitimate sphere in which young Iranian women can share their sexual concerns and increase their knowledge of sexuality. For example, I was amazed by the number of young women, mostly in their 20s, who attended the one-day workshop. Similar to my recent experience at Al-Zahra university, I was surprised by the questions and sexual concerns women raised during the workshop. The religious basis of the sexual information gave them the authority and power to seek help for their sexual worries and problems.

Unlike the older generations of Iranian women, younger women expect their husbands to respect their wishes and satisfy their needs. Many in the older generations of women have told of unpleasant or even 'torturous' sexual experiences with their husbands as their sexual needs were denied in marriage (Al-Sharmani, Rumminger 2015: 237; Sharifi 2018: 48). In the religious sex education workshops, younger women still learn about the importance of tamkin, but at the same time they learn that their sexual needs should also be satisfied at home.

More important, the discourse of religious sex education presents a different image of male sexuality - one in which a man is affectionate, caring, warm, and friendly towards his wife. Under the influence of Dehnavi's sex education, young men learn that they are responsible if their wife is sexually frustrated and unhappy in marriage. Polygamy is their religious legal right only if they can sexually satisfy all their wives. This image is contrasts with the general cultural view, as men are usually depicted as selfish sexual beings who only care about their own needs and desires.

Religious education for men dealing with the importance of women being sexually satisfied and teaching men how to give sexual pleasure reflect the extent of the social problems that have been caused by couples' sexual dissatisfaction. In order to preserve the well-being of the family and control Iranians' sexual lives it has become important to create a caring and loving image of a marital relationship. This new image redefines tamkin, not as a woman's duty and a man's right, but as a way of showing love and affection. In fact, they both should participate in increasing each other's sexual pleasure at home.

Dehnavi's religious sex education and other similar workshops function in a complicated and contradictory way. They only legitimise sexual intercourse between heterosexual married partners, and they deny women's sexual needs before marriage, encourage tamkin, fail to question a man's right to polygamy, and ignore women's 
lack of legal support in marriage and divorce, but at the same time they spread new knowledge about sexual relations and introduce new sexual concepts, such as mutual sexual pleasure and satisfaction, into Iranians' sexual lives. This new knowledge is particularly influential for religious youth, who, due to religious barriers, do not have access to other sources of learning about sexuality. However, in order to analyse both the regulatory and emancipatory aspects of this discourse, it is essential to see how young people, and especially young women, understand, define and practice tamkin and other sexual advice in the context of their lives.

\section{Conclusion}

Feminist scholars have criticised the perception of Islam and the Muslim world as a homogenous entity (Abu-Lughod 1998; Ahmed 1991; Badran 1995; Mir-Hosseini 1999; Mahmood 2005). They instead emphasise the historical, political, and sociocultural indicators that shape the individual practices and interpretations of Islamic laws and regulations in a variety of contexts. In this paper, I also have argued that the religious discourse of sexuality, which is based on Shari'a, is not fixed, as it re-justifies and re-interprets itself in relation to changes in society. In order to retain its control over people's sexual lives, the religious discourse is forced to address the issues and concerns that affect people's lives. Therefore, as we see in Iran, the religious discourse applies new methods of communication and different modes of presentation in order to reach a wider spectrum of people and especially youth. By doing so, the religious discourse of sexuality indirectly enables women to think about their sexual desires and sexual expectations in marriage, and by highlighting sex as an important aspect of married life it encourages young women to learn more about sex and increase their knowledge of sexuality.

Similar to what Abu-Loghod has argued, I show that 'it is not easy to put one's finger on how power works' in a specific context (2013: 6). To understand the relations of power and the complicated and even contradictory aspects of disciplinary discourses, we need to look for the possibilities for actions that such discourses create in the lives of women.

\section{References}

Abu-Lughod, L. (ed.). 1998. Remaking Women: Feminism and Modernity in the Middle

East. Princeton: Princeton University Press.

Abu-Lughod, L. 2013. Do Muslim Women Need Saving? Harvard University Press.

Adelkhah, F. 2004. Being Modern in Iran. New York: Columbia University Press.

Afary, J. 2009. Sexual Politics in Modern Iran. New York: Cambridge University Press. 
Ahmed, L. 1991. Women and Gender in Islam. New Haven: Yale University Press.

Al-Kulyani, M. I. Y. 1379. Al-Kafi (Volumes 1-6). Translated by: Mohammad Bagher Kamarei. Tehran: Daftar-e Motale'at va Ma'ref Eslami.

Alikhah, F. 2008. 'The Politics of Satellite Television in Iran.' Pp. 94-111 in Semati, M. (ed.). Media, Culture and Society in Iran: Living with Globalization and the Islamic State. New York: Routledge.

Al-Sharmani, M., Rumminger, J. 2015. 'Understanding Qiwamah and Wilayah through Life Stories.' Pp. 219-256 in Mir-Hosseini, Z., Al-Sharmani, M., Rumminger, J. (eds.). Men in Charge? Rethinking Authority in Muslim Legal Tradition. London: Oneworld Publication. Badran, M. 1995. Feminists, Islam, and Nation: Gender and the Making of Modern Egypt. Princeton: Princeton University Press.

Farnam, F., Pakgohar, M., Mirmohamadali, M., Mahmoodi, M. 2008. 'Effect of Sexual Education on Sexual Health in Iran.' Sex Education, Vol. 8, No. 2: 159-168.

Foucault, M. 1980. Power/Knowledge: Selected Interviews and Other Writings, 1972-1977. Sussex: The Harvester Press.

Haeri, S. 1989. Law of Desire: Temporary Marriage in Shi'i Iran. New York: Syracuse University Press.

Hoodfar, H., Assadpour, S. 2000. 'The Politics of Population Policy in the Islamic Republic of Iran.' Studies in Family Planning, Vol. 31, No. 1: 19-34.

Hoodfar, H. 2017. 'Turning Back the Clock: Population Policy and Human Right'. Pp. 230243 in Chase, A. T. (ed.). Routledge Handbook on Human Rights and the Middle East and North Africa. New York: Routledge.

Khamenei, S. A. 2013. Speech at the National Congress on Changes in the Population and Its Role in Social Changes. [online]. Tehran [cit. 28/10/2013]. Available from: http://farsi. khamenei.ir/speech-content?id=24344.

Mahdavi, P. 2008. Passionate Uprisings: Iran's Sexual Revolution. Stanford: Stanford University Press.

Mahmood, S. 2005. Politics of Piety: The Islamic Revival and the Feminist Subject. Princeton: Princeton University Press.

Moaveni, A. 2005. Lipstick Jihad: A Memoir of Growing Up Iranian in America and American in Iran. New York: Public Affairs.

Moghissi, H. 2002. Feminism and Islamic Fundamentalism: The Limits of Postmodern Analysis. London: Zed Books.

Mir-Hosseini, Z. 1999. Islam and Gender. Princeton: Princeton University Press.

Mir-Hosseini, Z. 2002. 'Tamkin: Stories from a Family Court in Iran.' Pp. 136-151 in Bowen, D. L., Evelyn, A. (eds.). Everyday Life in the Muslim Middle East. Indiana University Press. Mir-Hosseini, Z. 2004. 'Sexuality, Rights and Islam: Competing Gender Discourses in Postrevolutionary Iran'. Pp. 204-218 in Neshat, G., Beck, L. (eds.). Women in Iran from 1800 to the Islamic Republic. Champaign: University of Illinois Press.

Mir-Hosseini, Z. 2010. 'Criminalising Sexuality: Zina Laws as Violence Against Women in Muslim Contexts.' Pp. 19-49 in Mir-Hosseini, Z., Hamzic, V. (ed.). Control and Sexuality: The Revival of Zina Laws in Muslim Contexts. London: Women Living Under Muslim Laws. 
Najmabadi, A. 1998. 'Crafting and Educated Housewife in Iran.' Pp. 91-126 in Abu-Lughod, L. (ed.). Remaking Women: Feminism and Modernity in the Middle East. Oxford: Princeton University Press.

Sabbah, F. A. 1984. Woman in the Muslim Unconscious. New York: Pergamon Press. Salamat News. 2016. The State Policies to Increase the Population. [online]. Tehran [cit. 24/05/2016]. Available from: http://bit.do/eQW52.

Shahidian, H. 2008. 'Contesting Discourses of Sexuality in Post-Revolutionary Iran.' Pp. 101-139 in Ilkkaracan, P. (ed.). Deconstructing Sexuality in the Middle East. Aldershot: Ashgate Publishing Limited.

Sreberny, A., Khiabany, G. 2010. Blogistan: The Internet and Politics in Iran. London: I. B. Tauris.

Sharifi, N. 2018. Female Bodies and Sexuality in Iran and the Search For Defiance. New York: Palgrave Macmillan.

Tizro, Z. 2013. Domestic Violence in Iran: Women, Marriage and Islam. London: Routledge. Varzi, R. 2006. Warring Souls: Youth, Media, and Martyrdom in Post- Revolution Iran. Durham: Duke University Press.

@ BY-NC Nafiseh Sharifi, 2019.

@ BY-NC Institute of Sociology of the Czech Academy of Sciences, 2019.

Nafiseh Sharifi is a postdoctoral researcher at the University of Tehran. She has a PhD in gender studies from the School of Oriental and African Studies in London. Her book Female Bodies and Sexuality in Iran and the Search for Defiance was published in 2018 by PalgraveMacmillan. Contact email: nafise.sh@gmail.com. 